\title{
Donnai Barrow Syndrome: A Case Study in the School Environment
}

\author{
Alessandra Teles Sirvinskas Ferreira ${ }^{1}$, Isabel Cristina Nonato de Farias Melo², \\ Ruth Mariani ${ }^{3 *}$, Helena Rodrigues Lopes ${ }^{4}$
}

${ }^{1}$ Laís de Aimeida Teles e Moisés de Azevedo Teles, Rio de Janeiro, Brasil

${ }^{2}$ Edigerson Pontes Nonato e Leonil de Oliveira Nonato, Rio de Janeiro, Brasil

${ }^{3}$ Marlene Mariani de Oliveira, Rio de Janeiro, Brasil

${ }^{4}$ Luiz Carlos Rodrigues e Marlene dos Santos Rodrigues, Rio de Janeiro, Brasil

Email: alessandra_ufrj@yahoo.com.br, tencelisabel@yahoo.com.br,ruthmariani@yahoo.com.br,helenarodrigues@id.uff.br

How to cite this paper: Ferreira, A. T. S., de Farias Melo, I. C. N., Mariani, R., \& Lopes, H. R. (2018). Donnai Barrow Syndrome: A Case Study in the School Environment. Creative Education, 9, 56-66. https://doi.org/10.4236/ce.2018.91005

Received: December 11, 2017

Accepted: January 28, 2018

Published: January 31, 2018

Copyright $\odot 2018$ by authors and Scientific Research Publishing Inc. This work is licensed under the Creative Commons Attribution International License (CC BY 4.0).

http://creativecommons.org/licenses/by/4.0/

\section{c) (i) Open Access}

\begin{abstract}
Donnai-Barrow syndrome is a rare hereditary disease that affects several parts of the body. This article is a case study and aims to analyze and discuss the different pedagogical strategies used to teach a student with Donnai Barrow syndrome enrolled in the Early Childhood Education program, in the city of Rio de Janeiro, pointing out significant aspects, the barriers evidenced and possibilities for meeting the specific needs of this student. The research has a qualitative, case-study approach, with a student with Donnai Barrow syndrome, a senior student in Early Childhood Education (EI-5). Data collection was performed through the observations and strategies used by one of the researchers and author of this article, who also acted as a teacher to the student with the syndrome studied. The development of the activities and the connection between the pedagogical strategies used and the specific needs of the student were considered while the data were organized. The results indicated 1) the planned and articulated actions; 2 ) the constant exchange among the professional which resulted in pedagogical actions articulated between regular classroom teachers and specialists; 3) the constant research of the specific educational needs of the student with Donnai Barrow syndrome and the consequent progress and development of this student in the school environment.
\end{abstract}

\section{Keywords}

Special Education, Specialized Pedagogical Service, Donnai Barrow Syndrome, Inclusion

\section{Introduction}

This article was prompted by the questioning of how to meet the needs of a child 
with Donnai Barrow's Syndrome in a school enrolled in the last year of Early Childhood Education, here called EI-5, in the city of Rio de Janeiro. We have found it difficult to find bibliographical references with scientific papers on the necessary pedagogical adaptations for the specialized care for this syndrome. The papers most of the time has been reporting the clinical aspects of the deficiency, leaving the pedagogics aside (Torres, 2013; Araújo et al., 2015; Kantarci et al., 2011; Pober et al., 2009).

Donnai Barrow syndrome is a rare inherited, autosomal recessive disease that affects many parts of the body, with a prevalence of less than 1/1,000,000 births, about 50 cases are recorded around the world (Torres, 2013; Araújo et al., 2015).

This research analysed the daily life of a student with Donnai Barrow syndrome, enrolled in the last year of Kindergarten (here called HEY-5), in the city of Rio de Janeiro.

Access to school is already a big challenge for individuals with this syndrome which is what instigated this research and gave rise to this paper.

The current Brazilian educational legislation establishes that the so-called Specialized Educational Assistance (AEE) encompasses specific pedagogical actions focused on school inclusion of special education students wrapped in three groups: 1) high Skills/Giftedness, 2) Global Development Disorder and 3) other disabilities. This specialized care can be developed in special institutions through AEE centers and in regular schools through the Multifunctional Resource Classrooms (SRM)-spaces in regular schools intended exclusively to provide specialized support for special education students (BRASIL, 2005, 2008, 2009).

The school in this case study is an institution which serves only deaf children, and so deafness is considered normal. Only students with multiple disabilities participate in the inclusion process. The student with the Donnai Barrow syndrome analyzed in this case study is included in the group of students with multiple disabilities, and has been granted participation through AEE.

Therefore we aim to analyze and discuss the different pedagogical strategies used for teaching a student with Donnai Barrow syndrome, enrolled in early childhood education, pointing out significant aspects, highlighting the barriers and identifying the possibilities to meet the specific needs of this student. To do so, the types of communication used by the student were analysed. The different services received by the student in school were identified as well as the adaptations and strategies used by the professionals. It was also discussed how these aspects were related to the process of educational inclusion and the educational development experienced by the student.

\section{Methodology}

This research was the qualitative type and the approach chosen was the case study type because it was understood that these could favor the approach between the researcher and the research field (Minayo, 1992; Goldenberg, 1997), which revealed to be very complex from the very beginning. Collection of in- 
formation was done by recording both the observations and the analysis of the strategies used by one of the researchers of this article, who also served as a teacher of the student. Analytic categories were previously defined in order to guide this research, serving as indicators for the analysis of the information gathered. These categories and indicators were based on professional actions in the development of activities, as well as on the connection between pedagogical strategies used and the specific needs of the student.

Once the data was collected, an analysis of the content and the information obtained was performed. It revealed nuances of interaction between the strategies used and the student with Donnai Barrow syndrome, who was in process of inclusion at the school.

The survey was conducted in the early childhood sector of a school in the city of Rio de Janeiro. Data collection was about one student, the only one with the Donnai Barrow syndrome at that location. The student, 6 years old, presents total hearing loss since birth, does not make use of a prosthesis. He is gradually losing his vision and according to his last eye exam, the child has 25 degrees of myopia. He is presently not showing any characteristics of intellectual disabilities. He does though presents hypertelorism, which is a malformation of the skull of the baby during pregnancy and is characterized by a larger distance between the eyes and a delay in development. The student uses the basic form of communication, Libras (the Brazilian sign language).

This process of investigation was done from the perspective of this specific student's teacher-researcher.

To ensure the confidentiality of the student's information he has been identified as "DB".

\section{Research Finding and Discussion}

The findings of the research and the discussion are organized in such a way to understand: the syndrome, the professional contributions for the development of activities and the connection between the teaching strategies used and the specific needs of the student with the Donnai Barrow syndrome.

\subsection{The Syndrome Characteristics, Causes and Diagnosis}

Donnai Barrow syndrome is a rare inherited disease, affecting various parts of the human body, characterized by unusual facial features, diaphragmatic hernia, omphalocele, hypertelorism, agenesis of the Corpus Callosum, severe sensorineural deafness, in addition to severe myopia. First signs of these symptoms happen during childhood or neonatal stages. This syndrome is also known as Facio-oculo-acoustico-renal syndrome or kidney-Schepens syndrome (Torres, 2013). Donnai Barrow syndrome is due to mutations in the LRP2 gene, responsible for producing a protein called megalin, which operates in several signaling pathways, particularly in brain epithelia, the kidney and the eyes, organs often affected by this syndrome (Kantarci, Donnai, Noonan, \& Pober, 2011). 
How the syndrome presents itself will depend on the severity of the affected organs. The complete or partial agenesis of the Corpus Callosum is reported in almost all individuals medically diagnosed with Donnai Barrow syndrome. The Corpus Callosum is a brain structure of white color, located in the central region of the human brain and it is responsible for the connection between the two cerebral hemispheres, the right and the left. Its condition is extremely important, since the two hemispheres work together. In addition, this structure operates in the interpretation of information coming from the senses and in the processing of mental information interpretation. There can be other structural abnormalities in the brain, as well as delayed development and intellectual disabilities, affecting communication, mobility, interaction and access to information (Pober et al., 2009).

Facial features of this pathology have its similarities to other disorders such as the Kniest syndrome and Stickler syndrome, without, however, any of the skeletal anomalies seen in Donnai-Barrow syndrome. Individuals may have a partial or total hearing and/or visual loss (Pober et al., 2009).

The diagnosis of the syndrome is based on clinical aspects. In some cases, proteinuria is observed, which is a condition characterized by the elimination of high amounts of low molecular weight proteins in the urine of patients with this syndrome.

Due to the characteristics of this syndrome, it is worth noting a parallel with deafblindness that, according to the Swedish Association of the Deafblind (FSDB) (2009), is defined as follows:

A person is deafblind if he or she has so impaired sight and hearing as to give him obvious difficulties in his daily life. This is a functional definition, not strictly based upon measurements of sight and hearing, but on how the person adjusts to his/her handicaps and on his/her needs (FSDB, 2009, s/p).

According to this definition, to establish the deafblindness degree of an individual, it is observed the functionality and the practical use of the senses by that same individual.

Reyes (2004) presents a deafblindness classification into four groups. His classification takes into consideration the person's age at the time he/she developed the disability, the order of the appearance of the disabilities and the level of a person's functionality The Congenital Deafblindness Group is the group of people born with sight and hearing compromised. The Deafblindness Group encompasses those born deaf and lost that their vision in the course of their life, being educated as deaf until they lose their eyesight, usually dominating the Brazilian sign language (Libras) and/or oralism. Another group embraces those who are born blind and lose their hearing in the course of their life, being thus educated as blind, usually dominant in Braille and also being able to express themselves orally. In the last group, there are those who were born without either disability losing hearing and vision later on in life, communicating usually using 
oral language. There is also differentiation between being deafblind before language acquisition (pre linguistic) and being deafblind after language acquisition (post linguistic), depending on whether the two losses occurred before or after the individual had already acquired language.

\subsection{The School and Pedagogical Practices}

We believe that learning about the features and causes of the Donnai Barrow syndrome is very important to develop an effective educational program for the student.

According to Amaral (2002), Cader-Nascimento (2007), Dorado (2004), \& Maia (2004) when working with deafblind students, one needs to consider: when the disability occurred; the degree of each disability; the child's access to specialized care and the functional use of the most appropriate technology for each case. This information can assist in establishing a better communication strategy and a better stimulation strategy, as well as the use of more efficient technologies throughout a student's education. This information can also help to support specialists to effectively contribute to student's development.

Specialists working with that student should therefore have knowledge about deafblindness and about the different possible forms of communication, according to Brazilian law (BRASIL, 2009). They should establish a planned and systematic practice with appropriate material to facilitate communication and interaction. The school environment is of great importance in the interaction and development process for the students with deafblindness (Farias, 2007), because the interactions in social contexts contribute to the human learning and development process.

Vigostsky (1997) states that the social context is a strong driving force in the construction of learning and the consequent human development, especially for those people with disabilities The severity of a person's disability may be increased or decreased according to his/her role within a society (Maciel, 2000). Although the school is just a simple system, it offers developmental opportunities because it promotes interaction between people. Mediation, in this environment, needs to be carefully introduced because it can contribute to improve or worsen the development of a person with disabilities (Padilha, 2000). The school environment helps to give meaning and social representation to the person who, having potential value and being recognized as valuable, improves in his/her development.

Anache (2007) points out that the school has the possibility to provide a context to overcome stigma, breaking prejudices, attitudinal barriers and pedagogical obstacles thus making the process of inclusion, through pedagogy, truly inclusive.

This leads us to believe that the knowledge about pedagogical strategies used for teaching a student with Donnai Barrow syndrome will be able to contribute to an increasing realistic understanding of the effectiveness of social services in 
this context. This will help to meet the demands of other individuals with the same needs thus helping them to be inserted appropriately in the school environment. That same knowledge will also contribute to enable others to have a better understanding of the possibilities of action toward favoring the overcoming of communication barriers having arisen from the simultaneous loss of vision and hearing.

\subsection{Pedagogical Strategies}

At the school mentioned in this case study, there is a specialized service center (CAE) which provides support to the students, provides guidance to the teachers and provides students with multiple disabilities with the specific service during the school day when the student is not in the classroom. This center provides professionals such as: occupational therapists, educators, educational psychologists, physical therapists and special education teachers.

When the student with the Donnai Barrow syndrome first arrived at the school, CAE was informed and its contribution was promptly requested. CAE then had the student evaluated, a diagnostic evaluation, both individually and in a classroom to observe his level of interaction and his needs. After that, a meeting was held to guide teachers on appropriate forms of action towards this student.

By Brazilian law, sites that carry out specialized educational services must have appropriate infrastructure, with appropriate physical space, specialized professionals and suitable material (BRASIL, 2005). In this situation, the educational unit had an effective infrastructure, with professionals like the Libras teacher; an educational psychologist working on one-on-one in a private room; the Physical Education teacher and Arts teacher. All of them were bilingual teachers (knowing both Portuguese and Libras) and had resources available to produce teaching materials suitable for the student.

Two areas of the infrastructure were considered flawed. First, there was only one mediator to meet three students-one with Donnai Barrow syndrome (DB), another with Charge syndrome and the third one with Attention Deficit Hyperactivity Disorder (TDAH). Second, there wasn't a skilled Braille teacher for the development of the necessary skills for a person with vision loss. On the other hand, in order to overcome these shortcomings, tactile perception activities were developed for the student to improve this sense, which will be extremely useful in the future. We believe that these problems will very likely exert a negative impact. An inadequate pedagogical support hinders the student's development, while, according to Vigostsky (1997), an effective mediation at school favors the learning process in the immediate environment where the development occurs in a more direct way.

At school, the student "DB" studied in a regular room, in the morning, with another 6 deaf students, one of them with Charge syndrome, and another student with TDAH. The total number was of 7 students. There was a bilingual 
teacher and a mediator, helping those three students with multiple disabilities. Twice a week, the student "DB" had art classes; three times a week he had physical education and, four times a week he had Libras with a deaf teacher.

Twice a week, the student "DB" was having phono audiological treatment in his own school and, twice a week he was having one-on-one care in the CAE with a psychologist and a pedagogue.

All the educational work is done in Brazilian sign language (Libras), which is the first language of the deaf, in accordance with the school's pedagogical proposal of bilingual education. The Portuguese is taught as a second language, and it is focused on written form, since the oralism is only stimulated during speech therapies.

To teach both Portuguese and Libras visual materials are used. The student relates the picture representing a word with a written word in Portuguese and a picture representing the word in Libras. Games are also used to teach Libras as well as to stimulate the use of the Portuguese language.

The alphabet and numbers both in Portuguese and in Libras are placed on classroom walls. Videos in Libras related to the themes chosen by the teacher were also available to the students. Some of these videos were created by that school's working team. All the visual displays were enlarged so that the student "DB" could visualize better. When the videos were used, the student was relocated closer to the screen to see better. The videos were played repeatedly so that the student could see the details. Every time he was able to see it and understand what he saw, he would divert his attention from the video to show and explain what he saw and would end up missing the next scene. With repetition, the student "DB" managed to capture all of the content.

The work done in CAE is entirely related to the activities carried out in class. All themes developed were discussed and selected previously in a meeting with all the teachers and, later on, another meeting was held with teachers and professionals all together. In this second meeting teachers had an opportunity to present those themes to each one of the support specialists so they could work in synchrony. During this second meeting the professionals also could express their ideas showing different materials and options for adaptation so the work done with the student was better performed and the content was better delivered. Suggestions by the CAE professional team, such as, to present the activity vertically with a support on the table; to enlarge the letters and to use images with contrasting backgrounds and less details; to adjust the lighting and so on, were of great benefit to the student "DB". Those simple but efficient suggestions enabled him to see better, and because of that, promoted his better participation in the classroom and his confidence.

The school, as it was said previously, had all its structure focused on deafness, so the visual impairment was not the main focus and, therefore, the support team would find it difficult to adapt all materials for the Donnai Barrow syndrome student. Not only that, there was also the school's norms and regulations 
that were very strict. Bureaucracy was a constant source of delays and often teachers had to work against time to get those materials prepared in a timing manner. Having the proper support and working with preparation and planning are of great importance. As Bronfenbrenner (1996) and Vigostsky (1997) once put it, the role of mediation and the place and context to which a person is assigned are the keys to his/her learning and development.

Visual resources during communication and education in Libras contribute to deeper and meaningful content understanding. It is worth noting that at this school, Libras fills the entire environment. Libras is as common as a first language to both professionals and students, and because of this, the communication flows easily and contributes to constant learning.

In the communicative process, the student "DB" uses primarily the Libras. $\mathrm{He}$ already writes his name in Libras and knows his own sign and those of his classmates. With whom he has close relationships. He talks, plays, and interacts without much difficulty. Often, he copies his classmates' behavior and, at times, he is the leader of the game.

Earlier in the year 2016, he was already writing his first name on paper with the help of an aid. However, it was noticed that without help he would get easily distracted and he would not complete his tasks. The teacher and the mediator would sometimes need to let "DB" work on his own so that they could do their jobs and assist other students. That did not contribute to his development because he needed constant guidance and support to focus on what was being done.

"DB" shows very clearly that he likes to participate in activities and answer questions, which are entirely directed in Libras, especially when he has one-on-one sessions with a teacher. However, he gets distracted and ignores the question when in the company of classmates. DB can also recount the stories and lessons he has been seeing in the videos or that were told to him by the teacher. Sometimes, his classmates try to help him in the classroom. On several occasions, the help was about answers he could do on his own. The teacher discourages this kind of behavior so "DB" can enhance his skills. Not only that, it was noticed that "DB" usually prefers not to carry out the tasks alone and let others do it for him, tasks such as writing the name, tie his shoes, make a collage or drawing.

In fact, his sight impairment causes him difficulties in the performance of several the tasks and so "DB" prefers to let others do them for him. The specialist's challenge here is to awake this student's interest to do the activities on his own and to instill in him the importance of being self-sufficient. In this case, it is imperative that the teacher works together with the student's family to provide them with knowledge and support to keep the same methodology and approach at home. Meetings were then held with DB's mother to discuss such topics and make her familiar with the team's strategies in how to improve his autonomy.

It was established that at home the student "DB" should be encouraged to 
perform tasks such as changing his clothes, tying his shoes, serving his own food and, when it came to homework, the mother should only guide and not do it for him. His mother followed the guidelines as much as she could. She confessed that, occasionally, time was not sufficient and she could not remain within for so long. On these occasions she rushed through some activities and helped him more than she should.

\subsection{Positive and Negative Aspects}

The pedagogical practice were successful whenever:

*Teaching was done in Libras;

${ }^{*}$ The difficulties and speed of the student were respected through the process of learning;

${ }^{*}$ Interaction between students during activities was promoted;

${ }^{\star}$ The work team was committed to the search of alternative ideas in order to boost the student's development;

${ }^{*}$ The activities were planned well in advance, and the material was provided in a timely manner;

${ }^{\star}$ The activities were carried out in an interdisciplinary approach;

${ }^{\star}$ The professionals worked in accordance with themes and strategies applied both in classroom and in one-on-one sessions;

${ }^{\star}$ The materials used were readjusted according to the needs of the student;

${ }^{*}$ The CAE worked together as a team and was supportive in giving advice:

* "DB" was moved closer to the screen to see better;

*Proper lighting in the environment was used so "DB" could see better;

*The team worked with tactile stimulation;

*It was insisted that "DB" did his tasks autonomously;

* "DB" was allowed to answer questions and then reproduce something that he had been taught;

*The teacher or mediator gave "DB" individual attention in achieving his tasks;

${ }^{\star}$ The professionals worked together with the student's family.

As negative aspects, we observed that:

*At first hand, there was a lack of knowledge related to the DB syndrome, which compromised the work of the team;

${ }^{*}$ There was just one mediator for three students;

*There were not enough professionals specialized in the teaching of Braille;

${ }^{\star}$ There were no professionals specialized in the teaching of activities regarding the skills of daily life for a vision impaired student;

*There were delays, and even failure to produce new materials on account of bureaucratic obstacles.

\section{Conclusion}

Considering the aspects of gradual vision impairment, the student "DB" needs to be worked with by a professional mediator who has very specific training. As 
Viñas (2004) said, it is not efficient to share a student's mediator with two other students, because the first one's education will suffer from several gaps.

A bilingual environment with skilled professionals contributes to the successful development of an individual. He is constantly exposed to the language which enables him to communicate proficiently. It also broadens the possibilities of appropriate pedagogical intervention and the student socialization, transcending his limits and overcoming his obstacles.

An integrated and interdisciplinary approach provides good support to students in an organized way; contributes to the students' communication and cognitive development; and promotes their autonomy and their inclusion. The articulated work spreads knowledge and amplifies it, generating a creative dialogue and empowering a creative action.

The interaction in school contributes immensely to the student's development and allows, if not leads, to an expansion of cognitive experiences.

Therefore, 1) the constant exchange of insights and knowledge between professionals during meetings; 2 ) the pedagogical contributions between the teachers and experts while dealing with the student, and 3) the continuous research about the specific educational needs of the student with Donnai Barrow syndrome had, as a final result, assisted and improved the advancement and development of that student at school.

However, this study does not contain all the pedagogical proposals. Obviously, we don't pretend to have the absolute truth about this syndrome. Our aim here is to share a pedagogical experience that can be reproduced and improved in similar conditions. We hope that future contributions will allow improving this approach, as well as the learning environment for students with this specific need.

\section{References}

Amaral, I. (2002). A educação de estudantes portadores de surdocegueira. In E. F. S. Masini (Ed.), Do sentido, pelos sentidos, para o sentido (pp. 121-144). Niterói: Intertexto.

Anache, A. A. (2007). A pessoa com deficiência mental entre os muros da educação. In H. R. Campos (Ed.), Formação em psicologia escolar: Realidades e perspectivas (pp. 30-46). Campinas: Alínea.

Araújo, R. O., Sandoval, R. L., Medina, C. T. N., Cardoso, M. T. O., \& Canó, T. N. (2015). Relato de Caso: Síndrome de Donnai-Barrow. XXVII Congresso Brasileiro de Genética Médica. Ribeirão Preto, SP. 3 a 6 jun. de 2015.

http://www.oxfordeventos.com.br/geneticamedica/admin/trabalhosPDF/GM_P_DM_0 $\underline{40 . p d f}$

BRASIL (2005). Presidência da República Casa Civil. Subchefia para assuntos jurídicos. Decreto 5626 que regulamenta a Lei 10.436. Brasília, DF, 2005.

http://www.planalto.gov.br/ccivil_03/_ato2004-2006/2005/decreto/d5626.htm

BRASIL (2009). Conselho Nacional de Educação. Câmara de Educação Básica. Resolução $\mathrm{n}^{\circ}$ 04, de 02 de outubro de 2009.

http://portal.mec.gov.br/dmdocuments/rceb004\%2009.pdf

BRASIL (2008). Ministério de Educação e Cultura. Política Nacional de Educação Espe- 
cial na perspectiva da educação inclusiva. Brasília, DF, 2008.

http://portal.mec.gov.br/arquivos/pdf/politicaeducespecial.pdf

Bronfenbrenner, U., \& Ceci, S. J. (1996). A ecologia do desenvolvimento humano: Experimentos naturais e planejados. Tradução de Maria Adriana Veríssimo Veronese. Porto Alegre: Artes Médicas.

Cader-Nascimento, F. A. A. A., \& Costa, M. P. R. (2007). Descobrindo a surdocegueira: Educação e comunicação. São Carlos: Edufscar.

Dorado, G. M. (2004). Sistemas de comunicación de personas sordociegas. In D. A. Reyes (Ed.), La sordoceguera: Um análisis multidisciplinar (pp. 193-252). Madrid: ONCE.

Farias, S. S. P., \& Maia, S. R. (2007). O surdocego e o paradigma da inclusão. Inclusão, 26.

FSDB (2009). Association of the Swedish Deafblind. http://www.fsdb.org/artikel/184

Goldenberg, M. (1997). A arte de pesquisar: Como fazer pesquisa qualitativa em ciências socias. Rio de Janeiro: Record.

Kantarci, S., Donnai, D., Noonan, K. M., \& Pober, B. R. (2011). Donnai-Barrow Syndrome. In R. A. Pagon, M. P. Adam, H. H. Ardinger et al. (Eds.), Gene Reviews (pp. 1993-2017). Seattle, WA: University of Washington. https://www.ncbi.nlm.nih.gov/books/NBK1878/

Maciel, M. R. C. (2000). Portadores de deficiências: A questão da inclusão social. São Paulo Perspect, 14, 51-56.

Maia, S. R. (2004). A Educação do Surdocego: Diretrizes básicas para pessoas não especializadas. 93f. Dissertação (Mestrado em Distúrbio do Desenvolvimento). São Paulo: Universidade Presbiteriana Mackenzie.

Minayo, M. C. (1992). O desafio do conhecimento-Pesquisa qualitativa em saúde. São Paulo: Hucitec Ltda.

Padilha, A. M. L. (2000). Práticas educativas: Perspectivas que se abrem para a Educação Especial. Educação \& Sociedade, 71, 197-220.

Pober, B. R., Longoni, M., \& Noonan, K. M. (2009). A Review of Donnai-Barrow and Facio-Oculo-Acoustico-Renal (DB/FOAR) Syndrome: Clinical Features and Differential Diagnosis. Birth Defects Research Part A: Clinical and Molecular Teratology, 85, 76-81. https://www.ncbi.nlm.nih.gov/pubmed/19089858

Reyes, D. A. (2004). La sordoceguera: Uma discapacidad singular. In D. A. Reyes (Ed.), La sordoceguera: Um análisis multidisciplinar (pp. 135-159). Madrid: ONCE.

Torres, M. (2013). Síndrome Donnai-Barrow Síndrome de Holmes-Schepens-Síndrome Facio-oculo-acústico-renal Herança Autossómica Recessiva. As Doenças Raras. https://asdoencasraras.blogspot.com/2013/05/sindrome-donnai-barrow-sindrome-de.h tml

Vigotsky, L. S. (1997). Obras escogidas V: Fundamentos de defectologia. Madrid: Visor Dis.

Viñas, P. G. (2004). La educación de las personas sordociegas. Diferencias y proceso de mediación. In D. A. Reyes (Ed.), La sordoceguera: Um análisis multidiscipliar. Madrid: ONCE. 